\title{
The Position and Main Tendencies of Criminality in the Russian Federation
}

\author{
Olga Afanasieva \\ Law Institute of Russian University of Transport \\ Moscow, Russia \\ E-mail: afanasevaor@yandex.ru
}

\author{
Maria Goncharova \\ All-union Scientific Research Institute of the Ministry of \\ Internal Affairs of Russia \\ Moscow, Russia \\ E-mail: maria-g2009@yandex.ru
}

\author{
Pavel Afanasiev \\ Law Institute of Russian University of Transport \\ Moscow, Russia \\ E-mail: afanasevpb@mail.ru \\ Valentina Shiyan \\ Law Institute of Russian University of Transport \\ Moscow, Russia \\ E-mail: valentina-shiyan@yandex.ru
}

\begin{abstract}
In the scientific literature it has been repeatedly noted that the processes occurring in society have an impact on the state and tendencies of the development of criminality. The qualitative transformation of crime is evidenced by the tendencies of recorded crime noted in the article. The article presents the criminological characteristics of the state of crime in the Russian Federation and the Federal districts of the Russian Federation at the end of 2018, identified and analyzed the main tendencies of the development of criminality. The article notes the determinants that may have influenced the tendencies of modern crime. The results of the study led to the conclusion that an effective counteraction to criminality should be based on the evaluation of its real position, the identification of which is one of the important tasks not only of science but also of law enforcement and law application.
\end{abstract}

Keywords-criminal situation; criminality; crime situation; crime tendencies; criminal threats; transport crime; law and order; crime factors; determination

\section{INTRODUCTION}

Today, in high dynamism of social, economic and political processes, the effectiveness of law enforcement bodies in the field of counteracting criminality also depends on the depth of the comprehensive analysis and objective evaluation of the criminal situation in Russia and in some of its regions. A key element of this work is a scientifically based criminological analysis of criminality in the country and the identification of tendencies of its development in the nearest future.

The criminological analysis of the criminal situation [1] [2] is the basis of crime forecasting, which is an integral part of the unified system of forecasting the socio-economic development of the Russian Federation. However, the main purpose of the criminological analysis of the criminal situation is: to determine the key problems of social management and law enforcement bodies in the fight against criminality; identify priority areas of law enforcement from the standpoint of state and public interests; ensuring the solution of the management tasks set in the system of law enforcement bodies.

The presented comprehensive criminality analysis is the result of the study and evaluation of the totality of the criminal situation elements, based on a significant official statistics and aggregated information about external and internal conditions of the criminal situation in the country.

\section{The MAIN IndicATORS OF CRIMINALITY AT THE END OF 2018}

"Great crime reduction" (greatcrimedrop) is considered to be a global trend of the last 10-15 years [3]. Against the background of the decrease in the number of reported crimes all over the world, the statistically reported crime trends in Russia, with their own characteristics, are comparable with world ones. In Russia, the number of reported crimes annually decreases on average of $6 \%$.

In 2018, there was recorded the lowest value of the number of crimes over the past 20 years - $1991532(-3,3 \%$ by 2017$)$ and the number of persons committed crimes -931 107, decreased by 3,7\% ("Fig. 1"). 
2388476

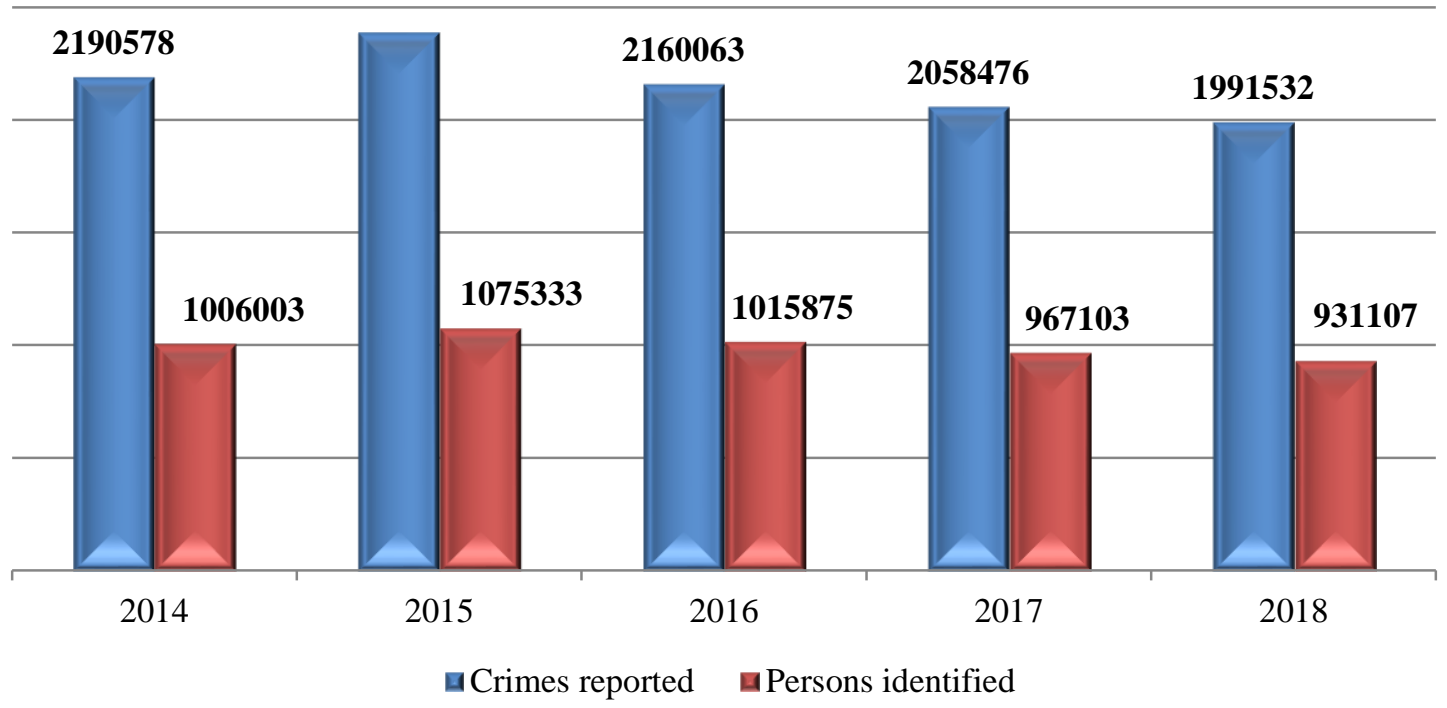

Fig. 1. Criminality dynamics in Russia in 2014-2018

The decrease in the number of reported crimes was recorded in all the federal districts of the Russian Federation ("Table I"), the largest number of them is registered in the
Central, Volga and Siberian Federal districts, accounting for the bulk $(56,8 \%)$ of all crimes.

TABLE I. DYNAMICS OF REPORTED CRIMES IN THE FEDERAL DISTRICTS OF THE RUSSIAN FEDERATION IN $2014-2018$

\begin{tabular}{|l|l|l|l|l|l|}
\hline \multirow{2}{*}{ Federal districts } & \multicolumn{5}{c}{ Years } \\
\cline { 2 - 6 } & 2014 & 2015 & 2016 & 2017 & 2018 \\
\hline Central Federal district & 517802 & 556490 & 505267 & 462824 & 450961 \\
\hline Increase / decrease, \% & $-1,6$ & 7,5 & $-9,2$ & $-8,4$ & $-2,6$ \\
\hline North-Western Federal district & 203681 & 227877 & 198645 & 188924 & 184139 \\
\hline Increase / decrease, \% & 1,5 & 11,9 & $-12,8$ & $-4,9$ & $-2,5$ \\
\hline Southern Federal district & 206147 & 238037 & 218875 & 213700 & 208898 \\
\hline Increase / decrease, \% & 16,3 & 15,5 & $-8,1$ & $-2,4$ & $-2,2$ \\
\hline Volga Federal district & 401875 & 451206 & 405325 & 392114 & 380451 \\
\hline Increase / decrease, \% & $-3,7$ & 12,3 & $-10,2$ & $-3,3$ & $-3,0$ \\
\hline Ural Federal district & 216176 & 229510 & 205447 & 201747 & 192376 \\
\hline Increase / decrease, \% & $-3,6$ & 6,2 & $-10,5$ & $-1,8$ & $-4,6$ \\
\hline Siberian Federal district & 393383 & 422926 & 382167 & 364252 & 299661 \\
\hline Increase / decrease, \% & $-2,4$ & 7,5 & $-9,6$ & $-4,7$ & $-4,5$ \\
\hline Far Eastern Federal district & 130090 & 134418 & 122529 & 116225 & 155994 \\
\hline Increase / decrease, \% & $-2,6$ & 3,3 & $-8,8$ & $-5,1$ & $-6,5$ \\
\hline North-Caucasian Federal district & 69695 & 75969 & 73885 & 69820 & 69987 \\
\hline Increase / decrease, \% & $-2,6$ & 9,0 & $-2,7$ & $-5,5$ & $+0,2$ \\
\hline
\end{tabular}

The value of the criminality rate in the country also decreased and it is 1355.9 crimes per 100 thousand people now $(-3,3 \%)$ ("Table II").

TABLE II. THE CRIMINALITY RATE DYNAMICS IN THE RUSSIAN FEDERATION IN 2014-2018

\begin{tabular}{|c|l|l|l|l|l|}
\hline \multirow{2}{*}{ Indicator } & Годы & \multicolumn{5}{|l|}{} \\
\cline { 2 - 6 } & 2014 & 2015 & 2016 & 2017 & 2018 \\
\hline $\begin{array}{c}\text { Criminality } \\
\text { rate }\end{array}$ & 1500,30 & 1632,95 & 1474,00 & 1402,2 & 1355,9 \\
\hline
\end{tabular}

Evaluating the degree of criminal defeat of the Federal districts in the Russian Federation, we note that the most difficult situation is in the Far Eastern, Siberian and Ural Federal districts, where the crime rate is higher than the allRussian one ("Table III"). 
TABLE III. ThE CRIMINALITY RATE IN THE FEDERAL DistRICTS OF THE RUSSIAN FEDERATION IN 2018

\begin{tabular}{|l|l|l|}
\hline \multicolumn{1}{|c|}{ Russian Federation } & Criminality rate & $\begin{array}{c}\text { Increase / } \\
\text { decrease, \% }\end{array}$ \\
\hline Russia & 1355,9 & $-3,3$ \\
\hline Far Eastern Federal district & 1897,1 & $+0,9$ \\
\hline Siberian Federal district & 1739,2 & $-7,7$ \\
\hline Ural Federal district & 1556,9 & $-4,7$ \\
\hline North-Western Federal district & 1319,8 & $-2,9$ \\
\hline Volga Federal district & 1287,8 & $-2,7$ \\
\hline Southern Federal district & 1270,5 & $-2,3$ \\
\hline Central Federal district & 1147,2 & $-2,8$ \\
\hline North-Caucasian Federal district & 712,4 & $-0,3$ \\
\hline
\end{tabular}

In all the federal districts, there is reported a decrease in the criminality rate, except the Far Eastern Federal district
$(+0.9 \%)$, which is due to including the Republic of Buryatia and the Trans-Baikal territory, the formerly part of the Siberian Federal district [4].

\section{THE CRIMINALITY STRUCTURE IN RUSSIA AT THE END OF 2018}

The analysis of the criminality structure in Russia makes it possible to prove that the "statistical face" are crimes against property $(55.91 \% ; 1113$ 366). Also, the criminality structure includes crimes against a person $(10.46 \% ; 208286)$; acts related to illicit drug trafficking, psychotropic substances or their analogues, potent substances (10.06\%; 200 306); economic crimes (5.5\%; 109 463), corruption crimes $(1.53 \% ; 30495)$, crimes of illegal turnover of weapons $(1.38 \% ; 27452)$; environmental crimes (1.2 percent; 23 899); terrorist crimes $(0.08 \% ; 1,679)$ and extremist crimes $(0.06 \% ; 1,265)$ ("Fig. 2").

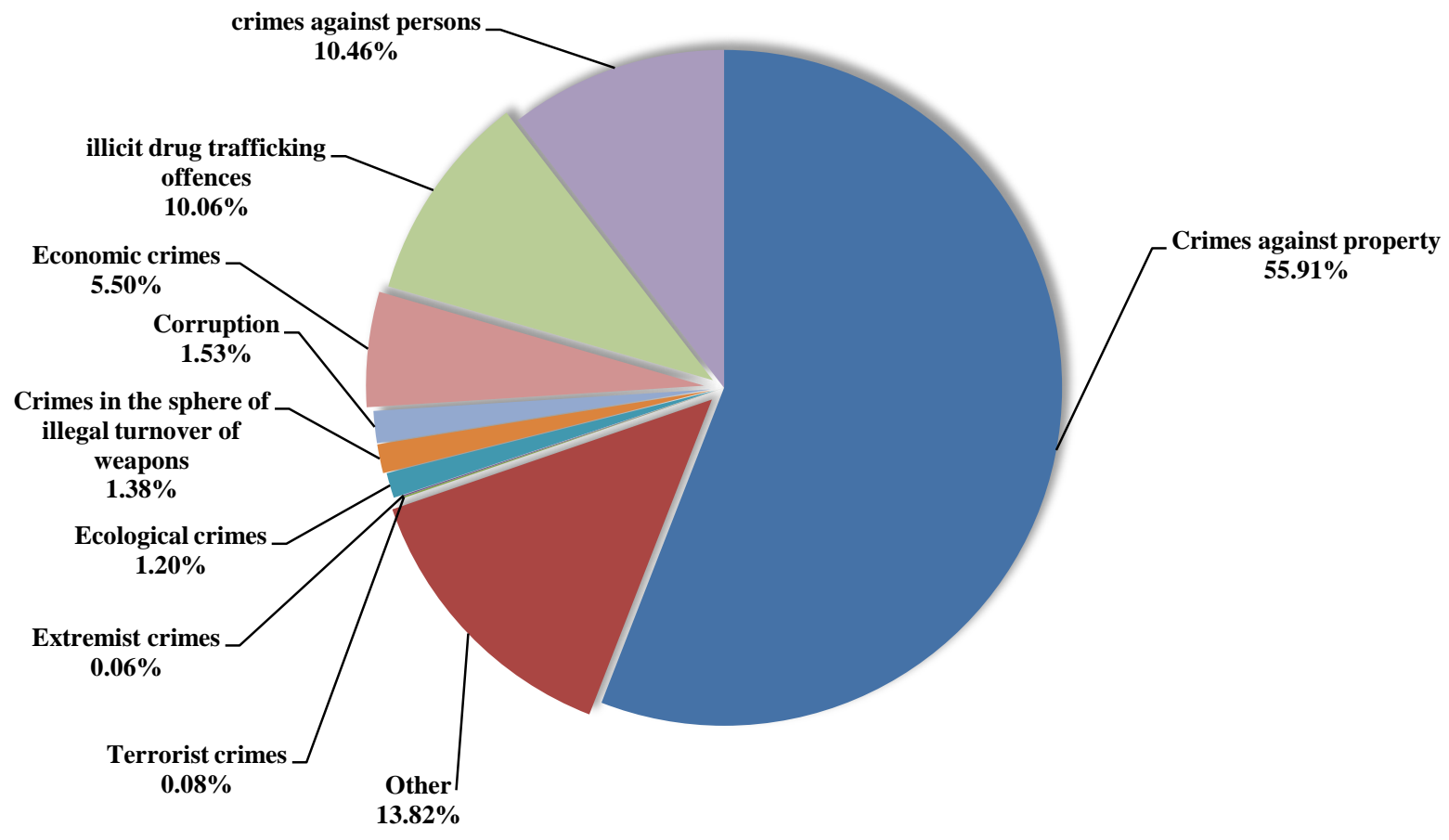

Fig. 2. The criminality structure in Russia at the end of 2018 .

Along with the reduction of quantitative crime indicators its negative qualitative changes are registered. The crime components have changed in terms of its severity: there is the increase in serious $(+6.8 \%)$ and especially serious $(+2.0 \%)$ crimes, which occurred against the background of the decrease in the proportion of crimes of minor offences and misdemeanor $(-0.2 \%$ and $-3.5 \%)$. However, the ratio of different crimes categories proportion as a whole is the same ("Table IV"). 
TABLE IV. C CRIMES DYNAMICS by SEVERITY AND THEIR PROPORTION IN THE RUSSIAN FEDERATION IN 2014-2018

\begin{tabular}{|c|c|c|c|c|c|}
\hline \multirow{2}{*}{ Crimes } & \multicolumn{5}{|c|}{ Годы } \\
\hline & 2014 & 2015 & 2016 & 2017 & 2018 \\
\hline in total & 2190578 & 2388476 & 2160063 & 205847 & 1991532 \\
\hline especially serious crimes & 127806 & 126360 & 107422 & 113712 & 112201 \\
\hline ratio of especially serious crimes proportion & 5,83 & 5,29 & 4,97 & 5,52 & 5,63 \\
\hline serious crimes & 403582 & 393295 & 350357 & 323591 & 335973 \\
\hline ratio of serious crimes proportion & 18,42 & 16,47 & 16,22 & 15,72 & 16,87 \\
\hline Misdemeanor & 728834 & 820354 & 748387 & 706636 & 660056 \\
\hline ratio of misdemeanor proportion & 33,27 & 34,35 & 34,65 & 34,33 & 33,14 \\
\hline minor offences & 930356 & 1048467 & 953897 & 914537 & 883301 \\
\hline ratio of minor offences proportion & 42,47 & 43,90 & 44,16 & 44,43 & 44,35 \\
\hline
\end{tabular}

\section{THE MAIN TENDENCIES OF CRIMINALITY IN 2018}

According to official statistics in the whole country there is a decreased in the number of murders and attempted murders $(-12.0 \% ; 8574)$, intentional grievous bodily harm $(-5.4 \% ; 23224)$, theft $(-4,1 \% ; 756395)$, fraud $(-3,5 \% ; 215$ $036)$, assignment or waste $(-7.0 \% ; 15452)$, robbery $(-$ $11.9 \%$; 50 111), banditry, (persons-17.9\%; 7 474), extortion (-1.1\%; 5 100), carjacking (-13.3\%; 19 460), terrorist crimes $(-10.3 \% ; 1679)$, extremist crimes $(-16.8 \%$; 1265 ), environmental crimes (from $-2.0 \% ; 23$ 899), and also illicit drug trafficking offences $(-4.0 \% ; 200306)$ and crimes in the sphere of illegal turnover of weapons $(-5.1 \%$; 27 452).

There is the decrease in the number of crimes committed while intoxicated: alchogolic $(351601 ;-7.0 \%)$, narcotic (14 $574 ;-38.9 \%)$ and toxic $(138 ;-17.9 \%)$, which may be the result of tightening penal responsibility for crimes committed while alcoholic intoxicated, as well as administrative responsibility for the violation of the alcoholic beverages trade rules in 2016-2017.

At the same time there is the increase in the number of crimes committed with the use of computer and telecommunication technologies (+92.8 per cent; 174 674), corruption $(+2.9 \% ; 30495)$ and economic crimes $(+4.2 \%$; 109 463), committed with the use of weapons, ammunition, explosives, explosive or imitating them devices $(+10,5$ per cent; 6003$)$, facts of banditry $(+3.5 \% ; 89)$ and organizing a criminal community (criminal organization) or participation in it $(+38.4 \% ; 274)$, beatings by persons subjected to administrative punishment $(+54.8$ per cent 2696$)$ and torture (+3.6\%; 3 103), as well as petty theft committed by persons subjected to administrative punishment $(+49.8 \%$; 13 861).

Among the registered crimes every third crime (634 027; $31.8 \%$ ) of completed investigation crimes are committed by persons committed crimes before.

Every third offence $(702323 ; 35.3 \%)$ is committed in a public place.

Among the more serious adverse qualitative changes in criminality with a self-determining content, are the following:
The occurrence and growth of technologically determined forms of criminality, poorly reflected in statistics due to high latency, which is provoked by informatization, cybernetization, internetization and robotization.

Thus, the annual growth of cybercrime is measured in tens of percent (in 2018: $+92 \%$ ). This process is irreversible, associated with the increasing penetration of Internet addiction, smartphone addiction, shopping addiction, cyberbullying and other negative manifestations of the forming digital society [5].

In 1985 , there were only 20 thousand users of telecommunication technologies in the world, by 2018 their number had increased by 200 thousand times and exceeded the threshold of 4 billion rub. At the end of 2013, only 72,5 million people were users of telecommunication networks in Russia. In April 2018, the audience of the Russian segment of the network (within domain names ".ru", ".su" and ".rf") has reached 90 million, it is the increase of more than $30 \%[6]$.

\section{A. The Increase in Reported Organized Criminality for the Past Three Years}

In 2017, the increase in the level of organized criminality was $5.7 \%$, in 2018 it was already 16,3\%, demonstrating the development vector opposite to the vector of whole criminality ("Fig. 3"). 


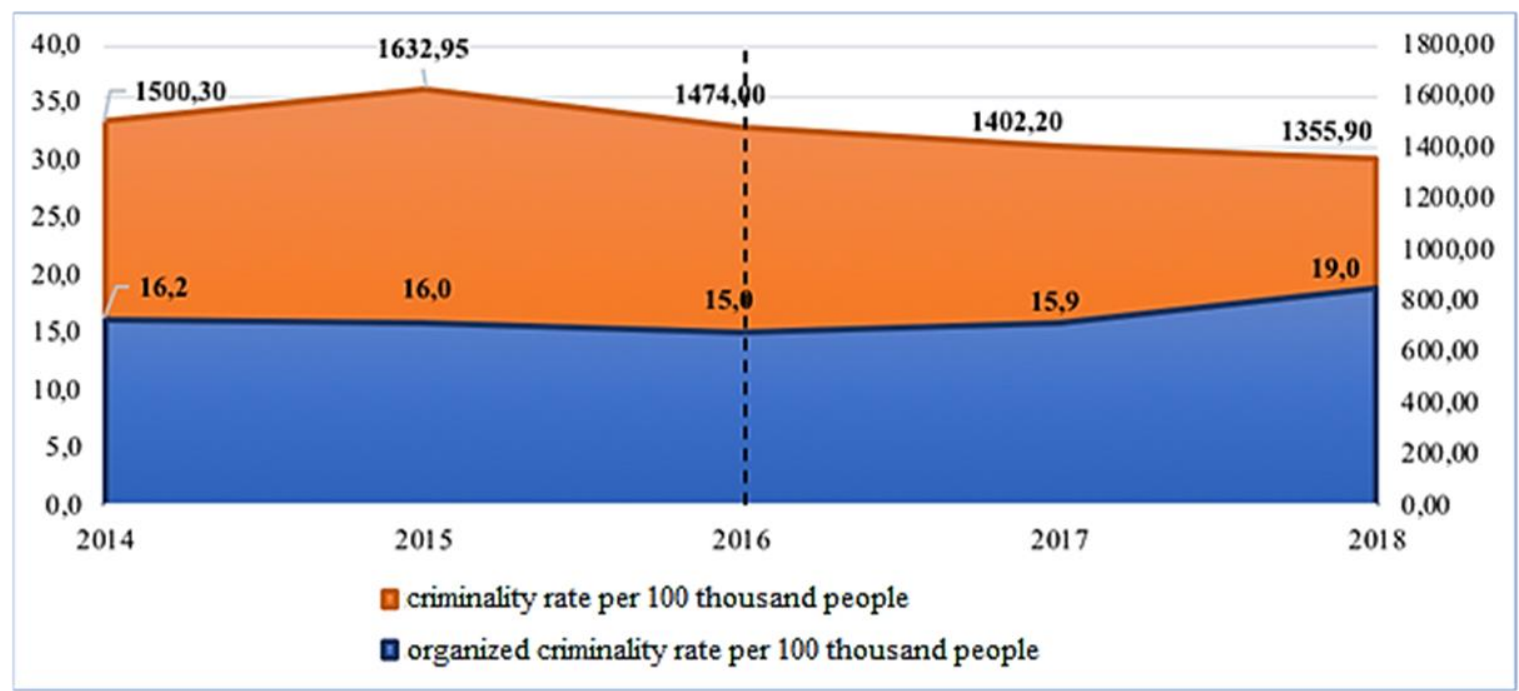

Fig. 3. Criminality rate dynamics in Russia in 2014-2018.

On the one hand, the protection of organized criminality from social control has decreased a little, because before efforts of law enforcement bodies kept the reported part of it within certain almost unchanged boundaries. Now, by identifying more acts, these efforts have reduced its latent part.

On the other hand, the growth of organized criminality, supported by the growth of recidivism and criminal professionalism, acting as its lowest link, displaces primary criminality from the "visible", registered part. The problem of countering criminality is exacerbated, in other words, the "load" on society from crime increases significantly.

\section{B. Remaining Conditions for the Increase of Latent Criminality (Natural)}

In the modern legal space, the lack of the domestic legislation efficiency is one of the significant factors that determine the possibility of the unhindered development of "uncontrolled" criminality. When more and more attacks are directed to "non-corporeal" goods, the traditional institutions of the criminal law protection and structures used by them cannot fully correspond to their purpose.

Actively discussed in the scientific community legislative initiative of the Supreme Court of the Russian Federation to modernize the concept of "crime" and introduce the concept "criminal offence" in the Criminal Code, aimed at reducing the number of persons sentenced to imprisonment, if adopted, will affect indicators of recorded criminality, moreover, will contribute a tendency to its decrease. However, it will not affect the effectiveness of countering new and modern criminal threats in general. The importance of this problem actualizes the issue of developing a mechanism for the radical transformation of criminal law, which can not be reduced to the fragmentary changes taking place today and the facts of fragmentation of the existing corpus delicti, as well as the casuistic way (using the analogy with prerevolutionary law).

The increase of undetected criminality is also the result of the implementation of low-quality legal norms with "internal" destructive potential. Such norms (for example, the article 2341 of the Criminal Code) do not take into account the rapidly changing objective reality and confrontation of law enforcement bodies.

Global factors determining the existence and development of criminality (socio-demographic, economic, political, ideological, etc.) are still relevant. They are not only unblocked, but also continue to deepen and multiply. This is evidenced by the data of expert surveys. Thus, in 2016-2017, Federal State Governmental University "AllRussian Research Institute of the MIA of Russia" conducted a survey of 479 experts who were current employees of the territorial bodies of the Russian MIA, students of the Academy of Management of the Russian MIA, All-Russian Advanced Training Institute of the MIA of Russia and the Tyumen Advanced Training Institute of the MIA of Russia on the issues of the real criminality and registration of discipline in Russia. Only 13,3\% of respondents noted the decrease in real and not in recorded criminality. According to the data of expert surveys rising unemployment, poverty, social inequality and social tensions are the main criminogenic factors. The value of these factors has become even more decisive over the past year.

Law enforcement bodies, first of all internal affairs bodies, register the majority of crimes $(92,9 \%)$. According to the results of sociological research, they have a sufficient level of confidence in order not to be accused of mass concealing illegal acts and contributing to their latinization. In May 2018, All-Russian Center for Public Opinion Research conducted a telephone interview on the topic: "Law enforcement and judicial bodies: the rating of rights and freedoms defenders".

Respondents (2,000 Russians aged 18 and over and 500 representatives of legal entities) were asked to evaluate the activity of the Russian Interior Ministry, the Prosecutor's office, the Federal security service, the Investigative Committee, Russian guard, courts of various instances and the Federal bailiff service. 
despite the decline in most statistical indicators, this is happening in areas that are difficult to implement social control.

\section{PERSONS IDENTIFIED FOR COMMITTING CRIMES IN THE RUSSIAN FEDERATION}

In 2018 , the tendency of the decrease in the majority of absolute indicators characterizing persons identified for crimes continued. At the same time, there was the increase in the number of unemployed criminals $(+8.7 \%)$, who committed crimes during the first year after the release from the correctional institution $(+5.2 \%)$, during the unserved part of the sentence after parole $(+2.4 \%)$, during the probation period with a conditional sentence $(8.5 \%)$ (see "Table V")

TABLE V. DYNAMICS OF THE NUMBER OF PERSONS IDENTIFIED FOR CRIMES IN THE RUSSIAN FEDERATION IN $2014-2018$

\begin{tabular}{|c|c|c|c|c|c|}
\hline Identified persons & 2014 & 2015 & 2016 & 2017 & 2018 \\
\hline In total & 1006003 & 1075333 & 1015875 & 967103 & 931107 \\
\hline Increase / decrease, \% & $-0,6$ & 6,9 & $-5,5$ & $-4,8$ & $-3,7$ \\
\hline Women & 158156 & 172178 & 148026 & 146916 & 145486 \\
\hline Increase / decrease, $\%$ & 1,2 & 8,9 & $-14,0$ & $-0,7$ & $-1,0$ \\
\hline Juveniles & 54369 & 55993 & 48589 & 42504 & 40860 \\
\hline Increase / decrease, $\%$ & $-10,5$ & 3,0 & $-13,2$ & $-12,5$ & $-3,9$ \\
\hline Pupils / students & 54870 & 55963 & 49971 & 45504 & 44430 \\
\hline Increase / decrease, $\%$ & $-10,3$ & 1,5 & $-10,7$ & $-8,9$ & $-2,4$ \\
\hline $\begin{array}{l}\text { Persons without a permanent } \\
\text { income }\end{array}$ & 663097 & 716638 & 664627 & 635517 & 601252 \\
\hline Increase / decrease, $\%$ & $-0,3$ & 8,1 & $-7,3$ & $-4,4$ & $-5,4$ \\
\hline Unemployed persons & 35012 & 22011 & 6146 & 4391 & 4775 \\
\hline Increase / decrease, $\%$ & $-8,0$ & $-37,1$ & $-72,1$ & $-28,6$ & 8,7 \\
\hline $\begin{array}{l}\text { Persons committed } \\
\text { crimes in the group }\end{array}$ & 138716 & 152072 & 141478 & 131165 & 127015 \\
\hline Increase / decrease, $\%$ & $-4,6$ & 9,6 & $-7,0$ & $-7,3$ & $-3,2$ \\
\hline $\begin{array}{l}\text { Persons committed crimes in an alcohol } \\
\text { intoxication }\end{array}$ & 311347 & 354397 & 395299 & 352062 & 326269 \\
\hline Increase / decrease, $\%$ & 4,4 & 13,8 & 11,5 & $-10,9$ & $-7,3$ \\
\hline $\begin{array}{l}\text { Persons committed crimes in an drug } \\
\text { intoxication }\end{array}$ & 29451 & 30523 & 25969 & 21370 & 11998 \\
\hline Increase / decrease, $\%$ & 16,8 & 3,6 & $-14,9$ & $-17,7$ & $-43,9$ \\
\hline Persons committed crimes before & 510122 & 556914 & 548382 & 541541 & 525475 \\
\hline Increase / decrease, $\%$ & 5,7 & 9,2 & $-1,5$ & $-1,2$ & $-3,0$ \\
\hline Persons convicted before & 308616 & 303494 & 272967 & 273379 & 270988 \\
\hline Increase / decrease, $\%$ & $-4,2$ & $-1,7$ & $-10,1$ & 0,2 & $-0,9$ \\
\hline $\begin{array}{l}\text { Within } 1 \text { year after } \\
\text { liberations }\end{array}$ & 37320 & 43634 & 37851 & 39223 & 41253 \\
\hline Increase / decrease, $\%$ & 7,9 & 16,9 & $-13,3$ & 3,6 & 5,2 \\
\hline After parole & 10843 & 9288 & 7635 & 8233 & 8432 \\
\hline Increase / decrease, $\%$ & $-18,5$ & $-14,3$ & $-17,3$ & 7,1 & 2,4 \\
\hline $\begin{array}{l}\text { During the trial period when the } \\
\text { conditional term } \\
\text { condemnation }\end{array}$ & 34520 & 31965 & 29341 & 34862 & 37815 \\
\hline Increase / decrease, $\%$ & 3,3 & $-7,4$ & $-8,2$ & 18,8 & 8,5 \\
\hline $\begin{array}{l}\begin{array}{l}\text { Foreign citizens } \\
\text { citizenship }\end{array} \\
\end{array}$ & 38501 & 41522 & 37684 & 35130 & 32728 \\
\hline Increase / decrease, $\%$ & $-1,2$ & 7,8 & $-9,2$ & $-6,8$ & $-6,8$ \\
\hline CIS nationals & 33475 & 36512 & 33279 & 31232 & 29203 \\
\hline Increase / decrease, $\%$ & $-1,5$ & 9,1 & $-8,9$ & $-6,2$ & $-6,5$ \\
\hline
\end{tabular}

The results of the analysis of relative indicators make it possible to state that in the structure of persons identified for crimes, the proportion of women $(+2.6 \%)$; pupils, students
$(+2.1)$; persons committed crimes before $(+0.7 \%)$ and previously convicted $(+2.2 \%)$ is growing (see "Table VI"). 
TABLE VI. DyNAMICS OF THE PROPORTION OF PERSONS IDENTIFIED FOR CRIMES IN THE RUSSIAN FEDERATION IN 2014-2018

\begin{tabular}{|l|l|l|l|l|l|l|}
\hline \multicolumn{1}{|c|}{ Proportion } & \multicolumn{1}{|c|}{$\mathbf{2 0 1 4}$} & $\mathbf{2 0 1 5}$ & $\mathbf{2 0 1 6}$ & $\mathbf{2 0 1 7}$ & \multicolumn{1}{c|}{$\begin{array}{c}\mathbf{2 0 1 8} \\
\text { Increase / } \\
\text { decrease by } \\
\mathbf{2 0 1 7}, \boldsymbol{\%}\end{array}$} \\
\hline Women & 15,7 & 16,0 & 14,6 & 15,2 & 15,6 & 2,6 \\
\hline Juveniles & 5,4 & 5,2 & 4,8 & 4,4 & 4,4 & 0 \\
\hline Pupils, students & 5,5 & 5,2 & 4,9 & 4,7 & 4,8 & 2,1 \\
\hline $\begin{array}{l}\text { Persons without a permanent } \\
\text { income }\end{array}$ & 65,8 & 66,5 & 65,4 & 65,7 & 64,6 & $-1,7$ \\
\hline Unemployed persons & 5,2 & 3,1 & 0,6 & 0,5 & 0,5 & 0 \\
\hline $\begin{array}{l}\text { Persons committed } \\
\text { crimes in the group }\end{array}$ & 13,8 & 14,1 & 13,9 & 13,6 & 13,6 & 0 \\
\hline $\begin{array}{l}\text { Persons committed crimes in an alcohol } \\
\text { intoxication }\end{array}$ & 31,0 & 33,1 & 38,9 & 36,4 & 35,0 & $-3,8$ \\
\hline $\begin{array}{l}\text { Persons committed crimes in a drug } \\
\text { intoxication }\end{array}$ & 2,9 & 2,9 & 2,6 & 2,2 & 1,3 & $-40,9$ \\
\hline Persons committed crimes before & 50,8 & 52,0 & 54,0 & 56,0 & 56,4 & 0,7 \\
\hline Persons convicted before & 60,4 & 54,3 & 49,8 & 50,5 & 51,6 & 2,2 \\
\hline $\begin{array}{l}\text { Foreign citizens and persons without } \\
\text { citizenship }\end{array}$ & 3,8 & 3,9 & 3,7 & 3,6 & 3,5 & $-2,8$ \\
\hline
\end{tabular}

In 2018, the all-Russian level (coefficient) of the criminal activity of the population decreased by $3.6 \%$ and it is 759.8 today (in $2017-788,2$ ).

The downward trend in this indicator is also characteristic of the federal districts. The exception was the
Far Eastern Federal district, where not only the increase in the level of criminal activity of the population $(+4.9 \%)$ was recorded, but also its maximum value (1198.4). The adverse situation is in the Urals (919.8) and Siberian (1072.1) Federal districts (see "Fig. 4").

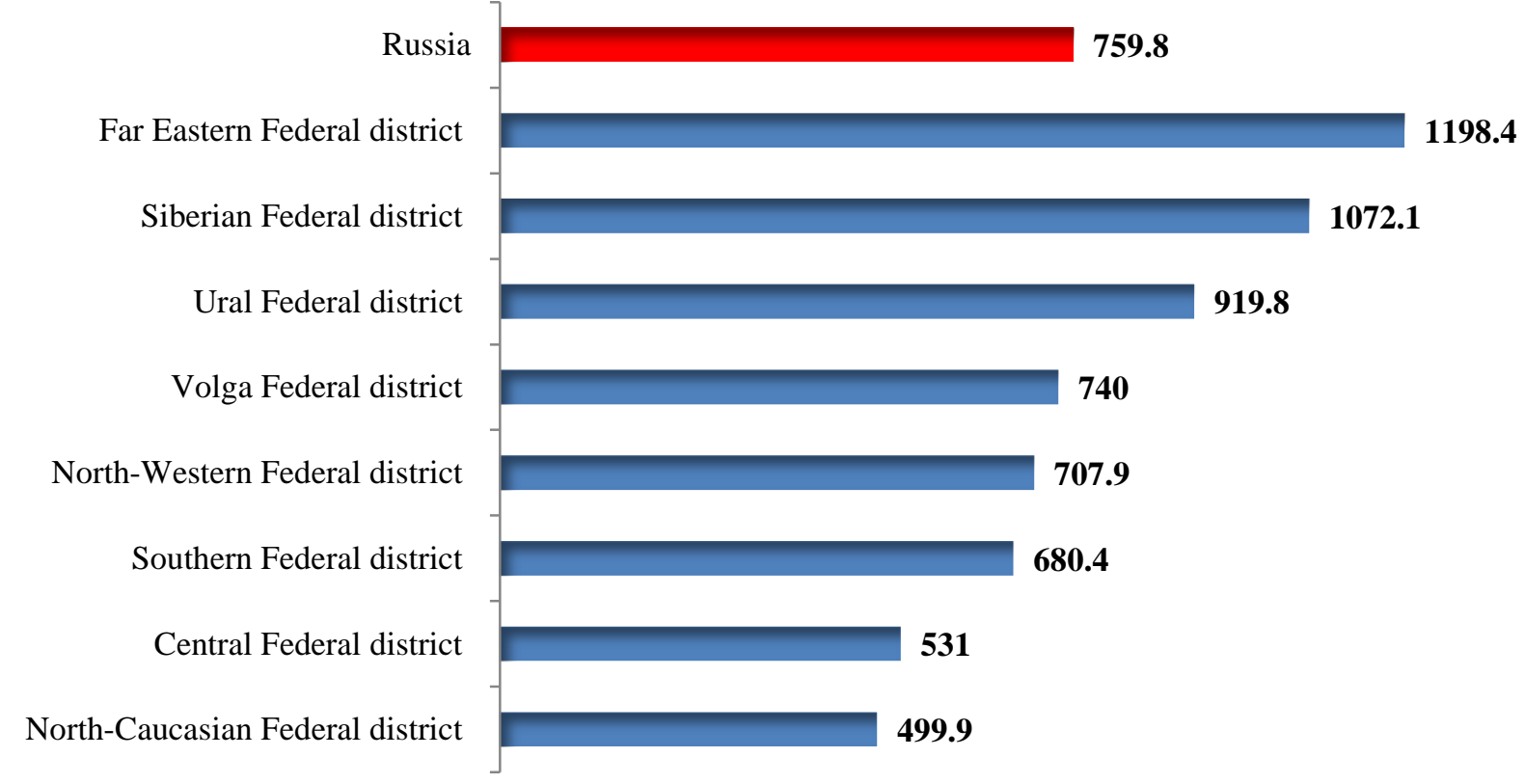

Fig. 4. Ranking of Federal districts according to the level of criminal activity of the population at the end of 2018.

The vast majority of persons identified for crimes are citizens of the Russian Federation.

The share of foreign citizens and persons without citizenship is insignificant (in $2018-3.5 \%$ ). Since 2016, this indicator has been steadily declining. The number of crimes committed by this category of persons has also decreased ($6.0 \%$ by 2017). This trend is the result of a comprehensive approach to combating illegal migration:
- the implementation of the priority program "Control and supervisory activity reform";

- the implementation of the risk-based approach while planning inspections of controlled subjects in the work of migration units;

- the development of the program of preventing risks of harm to the values protected by the law at the implementation of federal state control (supervision) in the field of migration; 
declining (a decline by $2014-18.5 \%$ ). Despite this fact, it is impossible to talk about positive trends, because: the territory of the Russian Federation. Only in 2018, 429.6 thousand verification measures were carried out to identify violations of migration legislation, 707,2 thousand administrative offences were revealed. There were taken 240.5 thousand decisions about unauthorized entry relating foreign nationals violated Russian legislation in the field of migration, 7.3 thousand - about deportation, 54.4 thousand about reduction of temporary stay term.

The greatest criminal activity is in the 30-49 and 25-29 years old age groups. During the study period, the proportion of juvenales did not exceed $5.4 \%$ of all persons identified for crimes. Over the past four years, this figure has been steadily
- the number of especially serious pre-investigated crimes (among those in production or registered in 2018) committed by juvenales or with their complicity increased by $5.6 \%$;

- - the proportion of the number of juvenales committed crimes in complicity remains high (in $2018-47.7 \%$ ), that indicates an increased degree of public danger not only of such crimes, but also of those who committed them. Since 2014, this figure has been growing consistently (see "Table VII").

TABLE VII. The Proportion DyNAMics of JuVENALES COMMITTED CRIMES IN COMPLICITY IN 2014-2018, \%

\begin{tabular}{|l|l|l|l|l|l|l|}
\hline \multicolumn{1}{|c|}{ Juvenales } & \multicolumn{1}{|c|}{$\mathbf{2 0 1 4}$} & $\mathbf{2 0 1 5}$ & $\mathbf{2 0 1 6}$ & $\mathbf{2 0 1 7}$ & $\begin{array}{c}\text { Increase / } \\
\mathbf{2 0 1 8}\end{array}$ & $\begin{array}{c}\text { decrease, \% by } \\
\mathbf{2 0 1 7}\end{array}$ \\
\hline $\begin{array}{l}\text { Persons committed } \\
\text { crimes in the group }\end{array}$ & 41.8 & 42.2 & 44.2 & 46.8 & 47.7 & 1.9 \\
\hline
\end{tabular}

Since 2017, the absolute figures of the number of juvenales committed crimes as part of an organized group or criminal community (criminal organization) are growing; in 2018 , the increase was $17.3 \%$;

In 2018, compared to 2017, the number of juvenales committed crimes during the unserved part of the sentence after parole increased by $53.3 \%$ (this figure in Russia was $+2.4 \%$ ).

In addition, according to Rosstat [8] there is the decrease in the number of:

- students received a certificate of secondary school ($4.1 \%$ by 2015 and $-57.4 \%$ by 2000 );

- additional education organizations on all types of children activity $(-4.7 \%$ by 2015$)$;

- youth sports schools (-42.4\% by 2015);

- children's music, art, choreography and art schools ($3.0 \%$ к 2015 году).

To date, it is impossible to completely eliminate the negative impact on the behaviour of juvenales:

- information and communication technologies, despite a number of preventive measures (for example, the Federal law from December 18, 2018 № 472-FL "On amendments to the article 151 of the Federal Law "On information, information technologies and about information protection" and the article 5 of the Federal Law "On protection of children from information that harms their health and development", establishing additional mechanisms to counter activity aimed at encouraging children to commit illegal acts; there blocked the access to 7.8 thousand information resources containing pornographic materials with persons under the age of 18; there blocked the access to 25.8 thousand information resources related to the activity of persons inclining juvenales to suicidal behaviour with the psychological influence through the Internet and social networks, etc.);

- informal associations of juvenales ("Columbine community", AUE, etc.), promoting culture of violence, popularizing ideas of terrorism and extremism;

- groups of death (Sea of whales, Milky way, Silent house, Wake me up at 4:20, f57, f58, etc.), carrying out their activity through social networks;

- games ("Blue whale", "Run or die", "Fairy fire", "Prison", etc.), created in the social network "Vkontakte".

These circumstances indicate the threat of a negative trend associated with a possible increase in crimes committed by juvenales or with their complicity.

\section{CONCLUSION}

In current socio-economic and political conditions of modern Russia, ensuring the law and order is the strategic direction that requires significant national efforts focused on strengthening the judicial and law enforcement institutions of the state and society.

In the sphere of countering criminality, all major decisions should be based on the reliable mechanisms of the criminological analysis, as well as regional and state program and target planning, which will create prerequisites for the maximum activation and improvement of organizational, managerial, law enforcement and operational activity of all bodies designed to control the criminal situation in the country.

The effective counteraction to criminality should be based on the evaluation of its real position, the identification of which is one of the important tasks not only of science but also of law enforcement and law application. The 
determination of the nature, reasons for the operation and true scale of criminality makes it possible to counteract the criminalization of society and the state, strengthen the rule of law and the judiciary.

\section{REFERENCES}

[1] A Comprehensive Analysis of the Criminality Position in the Russian Federation and Payment Options for its Development: Analytical Review. (2018). Antonyan, Yu.M., Brazhnikov, D.A., Goncharova, M.V. et al. Moscow : FSDU "All-Russian Research Institute of MIA of Russia".

[2] Afanasyeva, O.R., Brazhnikov, D.A., Goncharova, M.V., Malikov, S.V. , Shiyan, V.I. A Comprehensive Analysis of the Criminality Position in the Russian Federation at the End of 2016 and the Expected Tendencies of its Development: Analytical Review. (2017). Moscow: FSDU "Institute of the Ministry of Internal Affairs of Russia".

[3] Decree of the President of the Russian Federation from November 3, 2018 No. 632 "On Modification of the Federal Districts List Approved by the Decree of the President of the Russian Federation from May 13, 2000. No. 849".

[4] Komlev, Yu.Yu. (2018). Deviance and Crime in the Era of High-tech Consumerism and Glam-capitalism. Bulletin of the Kazan Law Institute of MIA Russia. T.9, 1, P. 23-34.

[5] Repetskaya, A.L. (2018). The Current Situation, Structure and Tendencies of Russian Criminality. Bulletin of Omsk University. Series "Law", 1 (54), P. 151-156.

[6] Russian Statistical Yearbook. (2018).StatisticalCollection/Rosstat. Moscow, 694p.

[7] URL: Telephone Interviews Polls [Electronic resource]// https://wciom.ru/index.php?id=238\&uid=9115 (date of access: 7.02.2019).

[8] The Main Results of the XXI Russian Internet Forum (RIF and CIB 2018). URL: https://2018. rif.ru/itogi (date of access: 2.02.2019). 